Dikirim: 10 Juli 2017 Diterbitkan: 15 Maret 2018

\section{Tuberculosis paru pada anak di Salatiga: pengaruh kondisi rumah dan pendapatan keluarga}

\section{Children with pulmonary tuberculosis in Salatiga: effect of housing condition and family income}

Namira Wadjir Sangadji \& Hari Kusnanto $^{1}$

\begin{abstract}
Purpose: This study aimed to analyze the social and environmental determinants associated with cases of childhood tuberculosis in the city of Salatiga 2015-2016. Method: This study was a case control involving 130 children. Cases were children aged $\leq 15$ years who were diagnosed tuberculosis by a doctor's examination based on the Indonesian pediatric association scoring system. Controls were children aged $\leq 15$ years who were not had tuberculosis by a doctor's examination based on the Indonesian pediatric association scoring system. Data were collected through structured interviews and direct measurement of ventilation area, room, humidity and home lighting and coordinate measurements with global positioning system to determine the position of tuberculosis case point. Results: The pattern of pulmonary tuberculosis cases in children was spread over densely populated areas. Room density was the biggest risk factor in the incidence of childhood tuberculosis in Salatiga. A social condition that affected pulmonary tuberculosis the most was family income. Conclusion: Active case finding is needed in low socio-economic groups and densely populated areas. Health promotion of healthy house requirements needs to be given to the community.
\end{abstract}

Keywords: pulmonary tuberculosis in children; room density; family income; spread of tuberculosis

\footnotetext{
${ }^{1}$ Departemen Biostatistik, Epidemiologi dan Kesehatan Populasi, Fakultas Kedokteran, Kesehatan Masyarakat dan Keperawatan, Universitas Gadjah Mada. (Email: ira.sangadji@gmail.com)
} 


\section{PENDAHULUAN}

Pencegahan, diagnosis dan pengobatan tuberkulosis pada orang dewasa lebih diprioritaskan daripada anak (1). Anak merupakan kelompok risiko tinggi karena kekebalan tubuh belum berkembang sempurna. Kasus pada anak memburuk menjadi tuberkulosis milier atau meningitis (2). Kasus tuberkulosis anak mencerminkan efektivitas program pengendalian seperti deteksi kasus, pelacakan kontak dan keberhasilan vaksinasi BCG (1).

World Health Organization (WHO) memperkirakan setiap tahun terdapat 1,3 juta kasus baru tuberkulosis anak di dunia (1). Tiga ratus empat anak yang kontak dengan penderita dewasa, $48 \%$ diantaranya positif (3). Salatiga termasuk kota dengan prevalensi kasus di atas standar nasional. Faktor yang memengaruhi prevalensi meliputi kondisi sosial dan lingkungan. Kondisi sosial dan geografis menimbulkan variasi kondisi lingkungan rumah, ekonomi, perilaku pencarian pengobatan dan kepercayaan atau mitos tertentu (4).

Survei sosial dan ekonomi nasional (SUSENAS) 2014 melaporkan 5,34\% penduduk kota Salatiga berpenghasilan kurang dari Rp 300.000,00. Penghasilan rendah berdampak terhadap gizi anak dan kondisi fisik rumah. Faktor geografis ikut berpengaruh, karena kota Salatiga dekat dengan Gunung Merbabu sehingga suhu udara lebih sejuk dan lembab (5). Kondisi lingkungan yang tidak memenuhi syarat memicu perkembangan mycobacterium tuberculosis (6). Penelitian sebelumnya mengkaji pengembangan obat, kerentanan, pelacakan kasus tetapi belum memperhatikan faktor sosial ekonomi dan geografis. Penelitian ini bertujuan untuk menganalisis determinan sosial dan lingkungan pada kasus tuberkulosis paru anak.

\section{METODE}

Penelitian ini merupakan penelitian observasi analitik dengan desain penelitian case control. Penelitian dilakukan di Kota Salatiga dengan mengambil semua data TB paru pada anak yang tercatat di Balai Kesehatan Paru (BKPM) Kota Salatiga dan Rumah Sakit Umum Daerah (RSUD) Kota Salatiga pada tahun 2015 2016. Penelitian ini dimulai pada tanggal 16 September 2016 - 16 April 2017. Populasi dalam penelitian ini adalah semua anak usia $\leq 15$ tahun yang bertempat tinggal di Kota Salatiga pada tahun 2015 - 2016.

Sampel penelitian terdiri dari kelompok kasus dan kelompok kontrol. Adapun kriteria inklusi dan eksklusi adalah sebagai berikut. Kriteria inklusi adalah a) Kasus adalah anak usia $\leq 15$ tahun yang tinggal di Kota Salatiga pada tahun 2015 - 2016 dan terdiagnosa TB paru melalui pemeriksaan dokter berdasarkan sistem skoring Ikatan Dokter Anak Indonesia (IDAI) dan tercatat dalam register rawat jalan BKPM dan RSUD Kota Salatiga pada tahun 2015-2016. b) Kontrol adalah anak usia $\leq 15$ tahun yang tinggal di Kota Salatiga pada tahun 2015-2016 dan tidak terdiagnosa TB paru melalui pemeriksaan dokter berdasarkan sistem skoring Ikatan Dokter Anak Indonesia (IDAI) dan tercatat dalam register (data suspect TB) BKPM Kota Salatiga pada tahun 2015-2016. Sementara kriteria eksklusi adalah a) Anak tinggal di rumah yang direnovasi dalam periode waktu 2 tahun sebelum diagnosis sampai dengan waktu penelitian, b) Responden yang menolak, c) Alamat yang tidak jelas, d) Kontrol yang tidak matching dengan kasus.

Besar sampel dalam penelitian ini menggunakan total sampling $1: 1$ antara kasus dan kontrol dengan total sampling 130 anak. Pengambilan sampel kasus dan kontrol dilakukan dengan pencocokan (individual matched) antara jenis kelamin dan umur kemudian disesuaikan dengan kriteria inklusi dan eksklusi. Pengumpulan data dilakukan dengan wawancara dan pengukuran langsung luas ventilasi dan luas ruangan serta melakukan pengukuran koordinat dengan alat Global Positioning System (GPS) untuk menentukan posisi titik kasus TB paru anak. Analisis bivariat dilakukan dengan menggunakan uji McNemar dan multivariat menggunakan conditional logistic regression. Tingkat kepercayaan yang digunakan adalah 95\%.

Variabel yang digunakan dalam penelitian ini adalah a) TB paru pada anak : anak usia $\leq 15$ tahun yang didiagnosis oleh dokter menggunakan skoring IDAI dan tercatat pada register rawat jalan BKPM dan RSUD Kota Salatiga pada tahun 2015-2016. Skala analisis 1=Sakit TB paru 0=Tidak Sakit paru; b) Penghasilan keluarga : jumlah uang yang diperoleh keluarga dari hasil bekerja per bulan (upah) dan dinyatakan dalam rupiah. Skala analisis $1=\leq \mathrm{UMR}$ (Rp. 1.300.000) 0 = > UMR (Rp. 1.300.000); c) Pendidikan ibu : jenjang pendidikan formal yang pernah dilalui oleh ibu atau pengasuh anak yang dominan berdasarkan ijazah terakhir yang dimiliki. Skala analisis 1 pendidikan dasar (tidak sekolah, SD/MI, SMP/MTs 2 pendidikan tinggi (SMA/MA/SMK, D1/D2/D3, D4, S1, S2, S3; d) Kepadatan kamar adalah luas lantai kamar tidur dibanding dengan jumlah anggota keluarga yang meng- gunakan kamar tidur. Kamar tidur yang dihitung adalah kamar yang digunakan tidur malam. Skala analisis $1=$ Padat ( 2 orang banding $<8 \mathrm{~m}^{2}$ ) $0=$ Tidak padat ( 2 orang banding $\geq 8 \mathrm{~m}^{2}$ ).

Kamar tidur meliputi pertama kondisi ventilasi yaitu keadaan lubang angin dan jendela yang berfungsi 
untuk proses pertukaran udara. Jendela kaca yang tidak dapat dibuka dan ditutup tidak dihitung sebagai ventilasi. Luas ventilasi dihitung dari luas lubang angin dan jendela kemudian dijumlahkan dari masingmasing jumlah tersebut. Luas lubang angin dan jendela yang diukur pada kamar anak dan ruang utama keluarga. Skala analisis $1=$ Tidak memenuhi syarat ( $<10 \%$ luas lantai) $0=$ Memenuhi syarat $(\geq 10 \%$ luas lantai). Kedua Kelembaban udara yaitu jumlah kadar air di udara dalam kamar tidur anak dan ruang utama keluarga. Skala analisis $1=$ Tidak memenuhi syarat $(<40->70 \%) \quad 0=$ Memenuhi syarat $(40 \%-70 \%)$. Ketiga, pencahayaan ruangan yaitu jenis lantai yang paling dominan di dalam rumah. Skala analisis 1=Tidak memenuhi syarat (lantai dari bahan tidak kedap air seperti tanah) $0=$ Memenuhi syarat (lantai dari bahan kedap air seperti plesteran dan keramik). Keempat, bahan bakar memasak yaitu jenis bahan bakar yang digunakan untuk memasak sehari hari. Skala analisis $1=$ Tidak memenuhi syarat (menimbulkan asap seperti kayu bakar/arang) $0=$ Memenuhi syarat (tidak menimbulkan asap seperti gas atau minyak tanah). Kelima, kebiasaan merokok dalam rumah yaitu terdapatnya anggota keluarga lain yang mempunyai kebiasaan merokok dalam rumah yang menyebabkan paparan pada anak. Skala analisis $1=$ ya, $0=$ tidak. Terakhir, riwayat kontak yaitu anak yang memiliki riwayat kontak karena tinggal dengan penderita TB paru dewasa. Skala analisis $1=$ ada riwayat $2=$ tidak ada riwayat.

\section{HASIL}

Kasus tuberkulosis paru anak terletak di daerah padat penduduk. Desa Blotongan mempunyai kasus terbesar, sementara desa Pulutan dan Kecandran tidak memiliki kasus.

Tabel 1 menunjukkan bahwa kelompok kasus dan kontrol tidak kontak dengan penderita tuberkulosis. Kelompok kasus memiliki kontak lebih besar daripada kontrol. Riwayat kontak terbesar dari kakek. Kelompok kasus memiliki kontak dengan kakek lebih besar dari kelompok kontrol. Anak yang kontak 2 tahun dengan kasus indeks memiliki proporsi terbesar. Anak yang tidak tidur sekamar dengan kasus indeks mempunyai proporsi terbesar, sementara proporsi anak yang tidak tidur sekamar dengan kasus indeks di kelompok kasus memiliki proporsi lebih besar dari kelompok kontrol.
Tabel 1. Ciri kelompok kasus kontrol menurut kontak

\begin{tabular}{lcc}
\hline \multicolumn{1}{c}{ Variabel } & $\begin{array}{c}\text { Kasus (\%) } \\
\mathbf{n = 6 5}\end{array}$ & $\begin{array}{c}\text { Kontrol (\%) } \\
\mathbf{n = 6 5}\end{array}$ \\
\hline Riwayat kontak & 15,38 & 4,62 \\
Ada & 84,62 & 95,38 \\
Tidak ada & & \\
Hubungan kontak & 4,62 & 1,54 \\
Ayah & 1,54 & 0 \\
Ibu & 9,23 & 1,54 \\
Kakek & 0 & 1,54 \\
Paman & & \\
Lama kontak & 6,15 & 0 \\
1 tahun & 6,15 & 3,08 \\
2 tahun & 1,54 & 0 \\
3 tahun & 1,54 & 0 \\
5 tahun & 0 & 1,54 \\
6 bulan & & \\
Tidur sekamar & 6,15 & 3,08 \\
Ya & 9,23 & 1,54 \\
Tidak & &
\end{tabular}

Tabel 2 menunjukkan proporsi responden terbesar baik kelompok kasus dan kontrol adalah anak bungsu, sudah diimunisasi BCG, diasuh ibu kandung, ibu sebagai ibu rumah tangga. Sementara proporsi terbesar pekerjaan ayah pada kelompok kasus adalah buruh sedangkan kelompok kontrol adalah pegawai swasta.

Tabel 2. Ciri kasus kontrol menurut karakteristik anak

\begin{tabular}{lcc}
\hline \multicolumn{1}{c}{ Karakteristik Anak } & Kasus (\%) & Kontrol (\%) \\
\hline Urutan lahir & 21,54 & 29,23 \\
Pertama & 4,62 & 7,69 \\
Tengah & 44,62 & 44,62 \\
Bungsu & 29,23 & 18,46 \\
Tunggal & & \\
Imunisasi BCG & 96,88 & 98,46 \\
Sudah imunisasi & 3,13 & 1,54 \\
Belum imunisasi & & \\
Status pengasuh & 64,62 & 56,92 \\
Ibu kandung & 35,38 & 43,08 \\
Bukan ibu kandung & & \\
Pekerjaan ibu & 33,85 & 23,08 \\
Buruh & 43,08 & 40 \\
Ibu rumah tangga & 3,08 & 9,23 \\
Pegawai negeri sipil & 12,31 & 10,77 \\
Pedagang & 7,69 & 16,92 \\
Pegawai swasta & & \\
Pekerjaan ayah & 47,69 & 35,38 \\
Buruh & 4,62 & 7,69 \\
Pegawai negeri sipil & 12,31 & 7,69 \\
Pedagang & 35,38 & 41,54 \\
Pegawai swasta & 0 & 4,62 \\
Petani & 0 & 3,08 \\
Tidak bekerja & & \\
\hline
\end{tabular}


Tabel 3 menunjukkan besar risiko yang berpengaruh terhadap TB paru anak adalah jenis lantai, kepadatan kamar, riwayat kontak.

Tabel 3. Odds ratio TB paru anak berdsarkan faktor kondisi lingkungan rumah

\begin{tabular}{|c|c|c|c|c|}
\hline \multirow{2}{*}{ Kasus } & \multicolumn{2}{|c|}{ Kontrol } & \multirow{2}{*}{ OR } & \multirow{2}{*}{ CI (95\%) } \\
\hline & $\mathbf{E}+$ & E- & & \\
\hline \multicolumn{5}{|l|}{$\overline{\text { Kepadatan kamar* }}$} \\
\hline Padat & 26 & 24 & 2,40 & $1,10-5,62$ \\
\hline Tidak Padat & 10 & 5 & & \\
\hline \multicolumn{5}{|l|}{ Jenis lantai } \\
\hline Tidak kedap air & 4 & 23 & 2,30 & $1,05-5,41$ \\
\hline Kedap air & 10 & 28 & & \\
\hline \multicolumn{5}{|c|}{ Kelembaban ruang utama } \\
\hline Lembab & 47 & 11 & 1,83 & $0,62-6,03$ \\
\hline Tidak lembab & 6 & 1 & & \\
\hline \multicolumn{5}{|c|}{ Kelembaban kamar anak } \\
\hline Lembab & 37 & 14 & 1,75 & $0,68-4,81$ \\
\hline Tidak lembab & 8 & 6 & & \\
\hline \multicolumn{5}{|l|}{ Ventilasi kamar } \\
\hline$<10 \%$ luas lantai & 40 & 14 & 1,55 & $0,62-4,07$ \\
\hline$\geq 10 \%$ luas lantai & 9 & 2 & & \\
\hline \multicolumn{5}{|l|}{ Ventilasi ruang utama } \\
\hline$<10 \%$ luas lantai & 37 & 13 & 1,18 & $0,48-2,91$ \\
\hline$\geq 10 \%$ luas lantai & 11 & 4 & & \\
\hline \multicolumn{5}{|l|}{ Cahaya ruang utama } \\
\hline$<6$ lux dan $>120$ lux & 16 & 23 & 1,43 & $0,72-2,91$ \\
\hline $60 \operatorname{lux}-120 \operatorname{lux}$ & 16 & 10 & & \\
\hline \multicolumn{5}{|l|}{ Cahaya kamar } \\
\hline$<6$ lux dan $>120$ lux & 31 & 16 & 1,33 & $0,59-3,08$ \\
\hline $60 \operatorname{lux}-120 \operatorname{lux}$ & 12 & 6 & & \\
\hline \multicolumn{5}{|l|}{ Merokok } \\
\hline Ya & 14 & 17 & 1,06 & $0,50-2,24$ \\
\hline Tidak & 16 & 18 & & \\
\hline \multicolumn{5}{|c|}{ Bahan bakar memasak } \\
\hline Berasap & 4 & 10 & 0,71 & $0,28-1,72$ \\
\hline Tidak berasap & 14 & 37 & & \\
\hline \multicolumn{5}{|l|}{ Riwayat kontak } \\
\hline Ada & 0 & 10 & 3,33 & $1,85-18,8$ \\
\hline Tidak ada & 3 & 52 & & \\
\hline
\end{tabular}

Tabel 4 menunjukkan besar risiko yang berpengaruh terhadap kejadian TB paru anak adalah penghasilan keluarga.

Tabel 4. Odds ratio TB pru anak berdasarkan faktor sosial

\begin{tabular}{|c|c|c|c|c|}
\hline \multirow{2}{*}{ Kasus } & \multicolumn{2}{|c|}{ Kontrol } & \multirow{2}{*}{ OR } & \multirow{2}{*}{ CI (95\%) } \\
\hline & $\mathbf{E +}$ & E- & & \\
\hline \multicolumn{5}{|c|}{ Pendidikan ibu* } \\
\hline Rendah & 8 & 17 & \multirow{2}{*}{1,30} & \multirow{2}{*}{$0,59-2,92$} \\
\hline Tinggi & 13 & 27 & & \\
\hline \multicolumn{5}{|c|}{ Penghasilan keluarga* } \\
\hline$\leq \mathrm{UMR}$ & 6 & 27 & \multirow{2}{*}{2,45} & \multirow{2}{*}{$1,17-5,48$} \\
\hline > UMR & 11 & 21 & & \\
\hline \multicolumn{5}{|l|}{ Umur ibu** } \\
\hline$<20$ Tahun & 2 & 5 & - & - \\
\hline 20 - 35 Tahun & 38 & 45 & 0,55 & $0,10-3,07$ \\
\hline > 35 Tahun & 25 & 15 & 0,30 & $0,54-1,64$ \\
\hline
\end{tabular}

Tabel 5 menunjukan bahwa variabel yang paling berkontribusi terhadap kasus TB paru pada anak di Kota Salatiga adalah model ketiga yaitu penghasilan keluarga dan kepadatan kamar.

Tabel 5. Conditional logistic regression

\begin{tabular}{lccc}
\hline \multirow{4}{*}{ Variabel } & Model 1 & Model 2 & Model 3 \\
\cline { 2 - 4 } & OR & OR & OR \\
& CI 95\% & CI 95\% & CI 95\% \\
& $\boldsymbol{P}$ Value & P Value & P Value \\
\hline Kepadatan & 2,37 & 2,23 & 2,44 \\
kamar & $1,04-5,40$ & $1,01-4,95$ & $1,12-5,35$ \\
& 0,04 & 0,04 & 0,02 \\
Penghasilan & 1,93 & 2,55 & 2,49 \\
keluarga & $0,84-4,47$ & $1,19-5,46$ & $1,19-5,22$ \\
& 0,12 & 0,05 & 0,01 \\
Riwayat kontak & 3,54 & 2,87 & \\
& $0,82-15,20$ & $0,73-11,22$ & - \\
Jenis lantai & 0,08 & 0,12 & \\
& 2,08 & & - \\
& $0,81-5,35$ & - & \\
BIC & 0,12 & & $\mathbf{8 7 , 3 5}$ \\
\hline
\end{tabular}

\section{BAHASAN}

Penelitian ini sejalan dengan studi di Gambia yang menunjukan pola penyebaran penyakit tuberkulosis di area padat penduduk (7). Kasus tuberkulosis paru anak terbesar di desa Blotongan, sementara desa yang tidak memiliki kasus adalah desa Pulutan dan Kecandran. Desa Blotongan merupakan lahan datar sehingga distribusi penduduk lebih padat dibandingkan dengan desa Pulutan dan Kecandran di lahan yang miring (8).

Kepadatan kamar memengaruhi kasus tuberkulosis paru anak. Probabilitas anak yang sakit, tidur di kamar dengan kepadatan tidak memenuhi syarat dua kali lebih besar daripada anak yang tidak sakit. Penelitian sebelumnya tidak menemukan hubungan kepadatan kamar dengan kasus tuberkulosis paru anak $(5,9)$. Hasil penemuan ini berbeda karena metode pengukuran. Namun, terdapat studi lain membuktikan kepadatan kamar merupakan faktor risiko tuberkulosis paru pada balita (10). Transmisi penularan terjadi di ruang ketika percikan dahak tersebar melalui udara atau tertinggal di ruang dalam waktu yang lama (11). Penularan virus terkait dengan kontak dengan penderita dan hubungan kedekatan tinggal dalam satu rumah. Risiko penularan dalam ruangan semakin meningkat seiring dengan gerakan udara terbatas pada ruang tertutup (12).

Penghasilan keluarga merupakan faktor risiko tuberkulosis paru anak. Penelitian ini menemukan keluarga berpenghasilan kurang dari UMR pada anak yang sakit dua kali lebih besar daripada anak yang tidak sakit. Penelitian di rumah sakit Prof. dr. Sulianti 
Saroso menunjukan hasil berbeda. Penelitian itu tidak menemukan hubungan kasus tuberkulosis paru anak dengan penghasilan keluarga (13). Perbedaan ini dapat disebabkan karena kategori (cut of point). Pendapatan menggambarkan kemampuan ekonomi berpengaruh terhadap aspek kehidupan lainnya, seperti perilaku sehat, pendidikan, dan perumahan. Keluarga dengan pendapatan tinggi dapat memenuhi kebutuhan anggota keluarga seperti gizi, tempat tinggal dan pemeliharaan kesehatan, sehingga menurunkan risiko tuberkulosis. Keterkaitan pendapatan secara timbal balik (14).

Memberikan edukasi kepada keluarga penderita tuberculosis tentang cara pencegahan dan penularan TB sangat penting dilakukan. Langkah-langkah yang perlu dilakukan meliputi pencarian kasus secara aktif serta melakukan penyuluhan kesehatan di daerah kumuh dan padat. Penelitian yang dilakukan di daerah Johar Baru menemukan bahwa penyuluhan kesehatan tentang TB dapat meningkatkan pengetahuan tentang pencegahan penularan TB sebesar 85,7\% (15). Pengetahuan tentang pencegahan penularan TB paru merupakan bekal utama untuk mencegah penularan dan penyebaran penyakit TB Paru.

Terdapat beberapa keterbatasan penelitian diantaranya adalah besar sampel sebesar 65 kasus dan 65 kontrol memiliki nilai power of test sebesar $41 \%$ jika OR yang digunakan adalah 2 karena besar sampel yang harusnya digunakan adalah 140 kasus dan 140 kontrol. Keterbatasan besar sampel disebabkan karena total jumlah kasus pada laporan di RSUD dan BP4 pada tahun 2015-2016 hanya berjumlah 71 kasus dan dari 71 kasus tersebut terdapat 2 responden yang menolak, 1 responden pindah kota dan 3 alamat yang tidak jelas. Untuk kontrol didapatkan 145 dan dari 145 tersebut terdapat 34 alamat yang tidak jelas dan 46 kontrol tidak matching dengan kasus. Pemilihan variabel penelitian untuk mengetahui pengaruh terhadap kasus TB paru pada anak kemungkinan belum dapat menggambarkan sacara keseluruhan permasalahan yang ada karena masalah yang mempengaruhi kasus TB pada anak begitu kompleks.

\section{SIMPULAN}

Kasus tuberkulosis paru anak tersebar di area padat penduduk. Kepadatan kamar merupakan faktor risiko terbesar pada kasus tuberkulosis paru anak di Salatiga. Sementara, kondisi sosial yang paling berhubungan adalah penghasilan keluarga. Penemuan kasus secara aktif perlu dilakukan pada kelompok sosial ekonomi rendah dan area padat penduduk.

\section{Abstrak}

Tujuan: Penelitian bertujuan menganalisis determinan sosial dan lingkungan pada anak dengan tuberkulosis paru di kota Salatiga. Metode: Penelitian case control melibatkan 130 anak. Kasus adalah anak usia $\leq 15$ tahun yang menderita tuberkulosis oleh pemeriksaan dokter berdasarkan sistem skoring ikatan dokter anak Indonesia (IDAI) dan tercatat di register rawat jalan balai kesehatan paru dan rumah sakit di kota Salatiga tahun 2015-2016. Kontrol adalah anak usia $\leq 15$ tahun yang tidak menderita tuberkulosis dan tercatat dalam register rawat jalan balai kesehatan paru dan rumah sakit di kota Salatiga tahun 2015-2016. Pengumpulan data dengan wawancara terstruktur dan pengukuran langsung luas ventilasi, luas ruangan, kelembaban dan pencahayaan rumah, mengukur koordinat dengan alat global positioning system untuk menentukan posisi titik kasus tuberkulosis anak. Hasil: Pola penyebaran kasus tuberkulosis paru anak tahun 2015-2016 tersebar pada wilayah padat penduduk. Kepadatan kamar adalah faktor yang paling berisiko pada kejadian tuberkulosis paru anak. Kondisi sosial yang paling berhubungan dengan tuberkulosis paru anak adalah penghasilan keluarga. Simpulan: Penemuan kasus secara aktif pada kelompok sosial ekonomi rendah dan area padat penduduk. Promosi kesehatan tentang rumah sehat harus diberikan kepada masyarakat.

Kata kunci: tuberkulosis paru; anak, kepadatan kamar; penghasilan keluarga; penyebaran kasus tuberkulosis

\section{PUSTAKA}

1. World Health Organization. Global tuberculosis report 2015. World Health Organization; 2015.

2. Shingadia,D. Book Tuberculosis in Children. Clinical Tuberculosis Fourth Edition. Hachite UK Company, pp. 189-199;2008.

3. Rutherford, M.E., Hill, P.C., Maharani, W., Apriani, L., Sampurno, H., Van Crevel, R. and Ruslami, R. Risk factors for Mycobacterium tuberculosis infection in Indonesian children living with a sputum smear-positive case. The International Journal of Tuberculosis and Lung Disease 2012;16(12), pp.1594-1599.

4. Musenge, E., Vounatsou, P., Collinson, M., Tollman, $\mathrm{S}$. and Kahn, K. The contribution of spatial analysis to understanding HIV/TB mortality in children: a structural equation modelling approach. Glob Health Action 2013;6, pp.38-48.

5. Dinas Kesehatan Kota Salatiga. Profil Kesehatan Kota Salatiga Tahun 2015. Salatiga;2014. 
6. Halim,R.D. Faktor risiko kejadian TB paru pada anak usia 1 - 5 tahun di Kabupaten Kebumen 2011. Universitas Gadjah Mada;2011.

7. Touray, K., Adetifa, I.M., Jallow, A., Rigby, J., Jeffries, D., Cheung, Y.B., Donkor, S., Adegbola, R.A. and Hill, P.C. Spatial analysis of tuberculosis in an urban west African setting: is there evidence of clustering?. Tropical Medicine \& International Health 2010;15(6), pp.664-672.

8. BPS. Kota Salatiga dalam angka; 2015.

9. Ngapiyem, R. and Haripurnomo, K. Faktor risiko infeksi TB pada anak yang kontak serumah dengan penderita TB Paru (+) di Kabupaten Magelang Propinsi Jawa Tengah. Universitas Gadjah Mada;2006.

10. Fitriatun, S., Sulistiyani, S. and Nurjazuli, N. Kondisi Rumah sebagai Faktor Risiko Tuberkulosis Paru Pada Balita yang Berkunjung Di BP4 Semarang Tahun 2002. Jurnal Kesehatan Lingkungan Indonesia 2002;1(2), pp.39-43.
11. Musadad, A. Hubungan faktor lingkungan perumahan dengan kejadian penularan penyakit tuberculosis paru di rumah tangga, pp 1, Puslitbang ekologi kesehatan, Depkes RI; 2006.

12. Lienhardt, C. From exposure to disease: the role of environmental factors in susceptibility to and development of tuberculosis. Epidemiologic reviews 2001;23(2), pp.288-301.

13. Wiharsini W. Hubungan Faktor Kontak, Karakteristik Balita dan Orang tua dengan Kejadian TB Paru pada Anak di RSPI Tahun 2012 Kesehatan Masyarakat; 2013.

14. Aditama, T.Y. Tuberculosis dan kemiskinan. Majalah Kedokteran Indonesia 2005;55(2): pp.49-50.

15. Ernawati, K., Wulansari, R., Damayanti, N. A., \& Djannatun, T. Health education on transmission prevention and use of masks in families with tuberculosis patient: the experience from Johar Baru, Central Jakarta. Berita Kedokteran Masyarakat, 34(1), 44-49 